\title{
Quasi-one-dimensional platinum compound/polymer composites
}

\section{Journal Article}

Author(s):

Bremi, Juliane; Caseri, Walter; Smith, Paul

Publication date:

2002

Permanent link:

https://doi.org/10.3929/ethz-b-000422625

Rights / license:

In Copyright - Non-Commercial Use Permitted

Originally published in:

e-Polymers 2(1), https://doi.org/10.1515/epoly.2002.2.1.109 


\title{
Quasi-one-dimensional platinum compound/polymer composites
}

\author{
Juliane Bremi, Walter Caseri *, Paul Smith
}

Eidgenössische Technische Hochschule (ETH), Department of Materials, CH-8092 Zürich, Switzerland; Fax 01-6321178; wcaseri@ifp.mat.ethz.ch

(Received: December 19, 2001; published: February 26, 2002)

\begin{abstract}
Films of polymers comprising the quasi-one-dimensional compounds $\mathrm{K}_{2}\left[\mathrm{Pt}(\mathrm{CN})_{4}\right] \mathrm{Br}_{0.3},\left[\mathrm{Pt}\left(\mathrm{NH}_{3}\right)_{4}\right]\left[\mathrm{PtCl}_{4}\right]$ (Magnus' green salt), or $\left[\mathrm{Pt}\left(\mathrm{NH}_{2} \mathrm{Oc}\right)_{4}\right]\left[\mathrm{PtCl} l_{4}\right](\mathrm{Oc}$ $=$ octyl) were prepared from homogeneous solutions followed by solvent evaporation. Above a percolation threshold of ca. $8-10 \% \mathrm{v} / \mathrm{v}$, the composites adopted the semiconductor behavior of $\mathrm{K}_{2}\left[\mathrm{Pt}(\mathrm{CN})_{4}\right] \mathrm{Br}_{0.3}$ or Magnus' green salt, respectively. In the case of $\left.\mathrm{Pt}\left(\mathrm{NH}_{2} \mathrm{Oc}\right)_{4}\right]\left[\mathrm{PtCl}_{4}\right]$, a network established in the gel state in organic solvents was retained in the composites. Upon orientation of the composites by drawing, dichroism of the materials comprising Magnus' green salt and polarized light emission with $\mathrm{K}_{2}\left[\mathrm{Pt}(\mathrm{CN})_{4}\right] \mathrm{Br}_{0.3}$ was observed.
\end{abstract}

\section{Introduction}

Quasi-one-dimensional compounds with a linear platinum backbone have found attention due to their extraordinary structure and their optical and electrical properties [1-4]. Prominent examples of these interesting materials are $\mathrm{K}_{2}\left[\mathrm{Pt}(\mathrm{CN})_{4}\right] \mathrm{Br}_{0.3}$ (a compound of the Krogmann salt type) [1-3,5-7] and $\left[\mathrm{Pt}\left(\mathrm{NH}_{3}\right)_{4}\right]\left[\mathrm{PtCl}_{4}\right]$ (Magnus' green salt) $[2,8]$, the existence of which dates back to the early $19^{\text {th }}$ century [9-11]. As a result of their quasi-one-dimensional structure, $\mathrm{K}_{2}\left[\mathrm{Pt}(\mathrm{CN})_{4}\right] \mathrm{Br}_{0.3}$ and Magnus' green salt exhibit intrinsic optical anisotropy [12-16]. Relatively short Pt-Pt distances in the backbone (2.9 and $3.25 \AA$, respectively) lead to significant Pt-Pt interactions [2,3,5-8], resulting in an enhancement in electrical conductivity of the otherwise insulating materials into the region of semiconductors or even conductors $[2,3,5,17,18]$; it should be noted in this context that the presence of impurities may raise the conductivity by orders of magnitude $[2,6,19,20]$. While $\mathrm{K}_{2}\left[\mathrm{Pt}(\mathrm{CN})_{4}\right] \mathrm{Br}_{0.3}$ is soluble in water, $\left[\mathrm{Pt}\left(\mathrm{NH}_{3}\right)_{4}\right]\left[\mathrm{PtCl}_{4}\right]$ only dissolves in hot hydrochloric acid from which it can be recrystallized. Recently, we reported on Magnus' salt derivatives of the type $\left[\mathrm{Pt}\left(\mathrm{NH}_{2} \mathrm{R}\right)_{4}\right]\left[\mathrm{PtCl}_{4}\right]$ where $\mathrm{R}$ is an alkyl group with at least 7 carbon atoms [8,21]. These compounds are soluble in hot organic solvents and form, interestingly, thermoreversible gels upon cooling already at concentrations below $1 \% \mathrm{v} / \mathrm{v}$. The electrical conductivity of $\left[\mathrm{Pt}\left(\mathrm{NH}_{2} \mathrm{R}\right)_{4}\right]\left[\mathrm{PtCl}_{4}\right]$ is observed to be well below that of Magnus' green salt and is in the range of electrical insulators [8]. However, partial oxidation is reported to substantially increase the conductivity in Magnus' salts $[19,20]$, and thus may lead to the formation of semiconducting or conducting networks.

To our knowledge, composites of polymers and the above quasi-one-dimensional platinum compounds have not been explored. Such materials might finally consist of 
conductive or semiconductive networks in polymer matrices or yield highly dichroic composites. Mixing of the individual quasi-one-dimensional compounds in the polymer matrix is expected to result in agglomerates of the isolated compounds. Here, a more promising method appears to be mixing polymers and (soluble) platinum complexes in homogeneous solution followed by removal of the solvent. In the following, we report on the preparation of such composites and some of their properties.

\section{Experimental part}

\section{Materials}

Platinum reactants were purchased from Johnson Matthew, poly(methyl methacrylate) $\left(M_{w}=120000 \mathrm{~g} / \mathrm{mol}\right)$ from Aldrich, poly(vinyl alcohol) $\left(M_{w}=100000 \mathrm{~g} / \mathrm{mol}\right)$ from Polysciences, and the other chemicals used from Fluka or Aldrich. $\mathrm{K}_{2}\left[\mathrm{Pt}(\mathrm{CN})_{4}\right] \mathrm{Br}_{0.3}$, Magnus' pink salt, and $\left[\mathrm{Pt}\left(\mathrm{NH}_{2} \mathrm{Oc}\right)_{4}\right]\left[\mathrm{PtCl}_{4}\right](\mathrm{Oc}=$ octyl) were synthesized using procedures described in the literature $[8,23]$.

\section{Characterization}

Differential scanning calorimetry (DSC) was performed with a DSC 200 from Netzsch under nitrogen atmosphere at heating rates of $10^{\circ} \mathrm{C} / \mathrm{min}$. UV/vis spectra were recorded on a Perkin Elmer Lambda 900, and photoluminescence spectra on a SPEX Fluorolog 3 (Model FL3-12). Film thicknesses were determined with a micrometer gauge. The electrical conductivities (dc) were measured with the 4-point method as described in the literature [22].

\section{Preparation of composites of $\mathrm{K}_{2}\left[\mathrm{Pt}(\mathrm{CN})_{4}\right] \mathrm{Br}_{0.3}$ and poly(vinyl alcohol)}

A quantity of $400 \mathrm{mg}$ poly(vinyl alcohol) was dissolved in $50 \mathrm{ml}$ water at $100^{\circ} \mathrm{C}$ under reflux. In another vessel, $40-400 \mathrm{mg} \mathrm{K} 2\left[\mathrm{Pt}(\mathrm{CN})_{4}\right] \mathrm{Br}_{0.3}$ were dissolved in ca. $15 \mathrm{ml}$ water; the quantity of the polymer was adjusted to yield composites with the final polymer $/ \mathrm{K}_{2}\left[\mathrm{Pt}(\mathrm{CN})_{4}\right] \mathrm{Br}_{0.3}$ ratios indicated in the text. The two solutions were combined at room temperature. The resulting solution was poured into a Petri dish, and a slight stream of air was conducted over the dish during two days, whereupon composite films formed which could readily be retrieved.

\section{Preparation of composites of $\left[\mathrm{Pt}\left(\mathrm{NH}_{3}\right)_{4}\right]\left[\mathrm{PtCl}_{4}\right]$ and poly(vinyl alcohol)}

A suspension of $156 \mathrm{mg}$ Magnus' pink salt in $25 \mathrm{ml}$ water was heated under reflux for $2 \mathrm{~h}$. The color of the solution turned to dark green-grey. After addition of $19 \mathrm{ml}$ conc. hydrochloric acid $(37 \% \mathrm{w} / \mathrm{w})$ and $73 \mathrm{ml}$ water, the color changed to green. The mixture was heated until the solids were dissolved completely. The resulting yellow solution was filtered through a cellulose filter, and the filtrate was concentrated to ca. $40 \%$ of its original volume in a rotary evaporator at ca. $60^{\circ} \mathrm{C}$ and $120 \mathrm{mbar}$. In a separate vessel, 20 - $400 \mathrm{mg}$ poly(vinyl alcohol) were dissolved in $50 \mathrm{ml}$ water at $100^{\circ} \mathrm{C}$ under reflux, the quantity depending on the polymer/[ $\left.\mathrm{Pt}\left(\mathrm{NH}_{3}\right)_{4}\right]\left[\mathrm{PtCl}_{4}\right]$ ratio indicated in the text. The two solutions were combined, and green films of the 
composite material were obtained as described above for the $\mathrm{K}_{2}\left[\mathrm{Pt}(\mathrm{CN})_{4}\right] \mathrm{Br}_{0.3} /$ poly(vinyl alcohol) films.

\section{Preparation of composites of $\left[\mathrm{Pt}\left(\mathrm{NH}_{2} \mathrm{Oc}\right)_{4}\right]\left[\mathrm{PtCl}_{4}\right]$ and poly(methyl methacrylate)}

A quantity of 100 - $300 \mathrm{mg}$ poly(methyl methacrylate) was dissolved in $4-13 \mathrm{ml}$ chloroform at $60^{\circ} \mathrm{C}$, depending on the polymer/[Pt $\left.\left(\mathrm{NH}_{2} \mathrm{R}\right)_{4}\right]\left[\mathrm{PtCl}_{4}\right]$ ratio indicated in the text. In another vessel, $30-45 \mathrm{mg}\left[\mathrm{Pt}\left(\mathrm{NH}_{2} \mathrm{Oc}\right)_{4}\right]\left[\mathrm{PtCl}_{4}\right]$ were dissolved in $9-13 \mathrm{ml}$ chloroform at $60^{\circ} \mathrm{C}$. Both solutions were mixed at $60^{\circ} \mathrm{C}$. The solutions were slowly cooled to room temperature. During this period, a pink gel formed. The gel was transferred into a petri dish and the solvent was evaporated at room temperature under a slight stream of air for a few hours, yielding the desired composite films.

\section{Results and discussion}

\section{Composites with $\mathrm{K}_{2}\left[\mathrm{Pt}(\mathrm{CN})_{4}\right] \mathrm{Br}_{0.3}$}

The synthesis of $\mathrm{K}_{2}\left[\mathrm{Pt}(\mathrm{CN})_{4}\right] \mathrm{Br}_{0.3}$ is well established, and we selected for this purpose a standard procedure described in the literature [23]. Bromation of the starting material $\mathrm{K}_{2}\left[\mathrm{Pt}(\mathrm{CN})_{4}\right]$ yielded $\mathrm{K}_{2}\left[\mathrm{Pt}(\mathrm{CN})_{4}\right] \mathrm{Br}_{2}$, which was isolated, dissolved and treated with the appropriate amount of $\mathrm{K}_{2}\left[\mathrm{Pt}(\mathrm{CN})_{4}\right]$. Finally, typical $\mathrm{K}_{2}\left[\mathrm{Pt}(\mathrm{CN})_{4}\right] \mathrm{Br}_{0.3}$ crystals with the appearance of copper were obtained in the form of large needles. In order to prepare composites, these needles were dissolved in water, and after addition of an aqueous poly(vinyl alcohol) solution, composite films with thickness between 10 and $70 \mu \mathrm{m}$ were obtained after evaporation of the water. Materials with $\mathrm{K}_{2}\left[\mathrm{Pt}(\mathrm{CN})_{4}\right] \mathrm{Br}_{0.3}$ contents in the range of $10-50 \% \mathrm{w} / \mathrm{w}$ were thus prepared, corresponding to $5-33 \%$ $\mathrm{v} / \mathrm{v}$ (calculated with densities of $2.64 \mathrm{~g} / \mathrm{cm}^{3}$ for $\mathrm{K}_{2}\left[\mathrm{Pt}(\mathrm{CN})_{4}\right] \mathrm{Br}_{0.3}[5]$ and $1.3 \mathrm{~g} / \mathrm{cm}^{3}$ for poly(vinyl alcohol) [24]). Optical micrographs of composites with $10 \% \mathrm{w} / \mathrm{w}(5 \% \mathrm{v} / \mathrm{v})$ of the platinum compound revealed short birefringent needles of typical lengths of 10 $50 \mu \mathrm{m}$ and aspect ratios around 5 (Fig. 1). At a $\mathrm{K}_{2}\left[\mathrm{Pt}(\mathrm{CN})_{4}\right] \mathrm{Br}_{0.3}$ content of $40 \% \mathrm{w} / \mathrm{w}$ $(25 \% \mathrm{v} / \mathrm{v})$, a dense web of needles of $100-300 \mu \mathrm{m}$ length and aspect ratios around 20 was observed in optical micrographs (Fig. 2).

The bulk electrical conductivity of the composites increased from $10^{-10} \mathrm{~S} / \mathrm{cm}$ for the composite with $10 \% \mathrm{w} / \mathrm{w}(5 \% \mathrm{v} / \mathrm{v})$ to $9 \cdot 10^{-6} \mathrm{~S} / \mathrm{cm}$ with $20 \% \mathrm{w} / \mathrm{w}(11 \% \mathrm{v} / \mathrm{v})$ and remained constant at about $10^{-5} \mathrm{~S} / \mathrm{cm}$ with $30-50 \% \mathrm{w} / \mathrm{w}(17-33 \% \mathrm{v} / \mathrm{v}) \mathrm{K}_{2}\left[\mathrm{Pt}(\mathrm{CN})_{4}\right] \mathrm{Br}_{0.3}$. Hence, the percolation threshold appeared to be located around $10 \% \mathrm{v} / \mathrm{v}$. Obviously, the conductivity of the $\mathrm{K}_{2}\left[\mathrm{Pt}(\mathrm{CN})_{4}\right] \mathrm{Br}_{0.3} /$ poly(vinyl alcohol) composites above the percolation threshold fell in the range of that of a semiconductor. The conductivity of a pressed pellet (diameter $1.3 \mathrm{~cm}$, thickness $0.5 \mathrm{~mm}$ ) of $\mathrm{K}_{2}\left[\mathrm{Pt}(\mathrm{CN})_{4}\right] \mathrm{Br}_{0.3}$ was found to be $1.5 \cdot 10^{-4} \mathrm{~S} / \mathrm{cm}$. The temperature dependence of semiconductors with a single thermally activated conduction process ensues the relation $\ln \left(\sigma / \sigma_{0}\right)=-E_{\mathrm{a}} /\left(k_{\mathrm{B}} T\right)$, where $\sigma$ is the electrical conductivity, $\sigma_{0}$ a material-dependent constant, $E_{a}$ the activation energy, $k_{\mathrm{B}}$ Boltzmann's constant, and $T$ the temperature (in $\mathrm{K}$ ) $[25,26]$. It was found that composites with $\mathrm{K}_{2}\left[\mathrm{Pt}(\mathrm{CN})_{4}\right] \mathrm{Br}_{0.3}$ of contents of 11 and $17 \% \mathrm{v} / \mathrm{v}$ indeed followed approximately this linear relation in the investigated temperature range between 345 and $395 \mathrm{~K}$ (an example is given in Fig. 3). From the slopes, activation energies between 1.0 and $1.5 \mathrm{eV}$ were calculated for films of these two $\mathrm{K}_{2}\left[\mathrm{Pt}(\mathrm{CN})_{4}\right] \mathrm{Br}_{0.3}$ contents. 


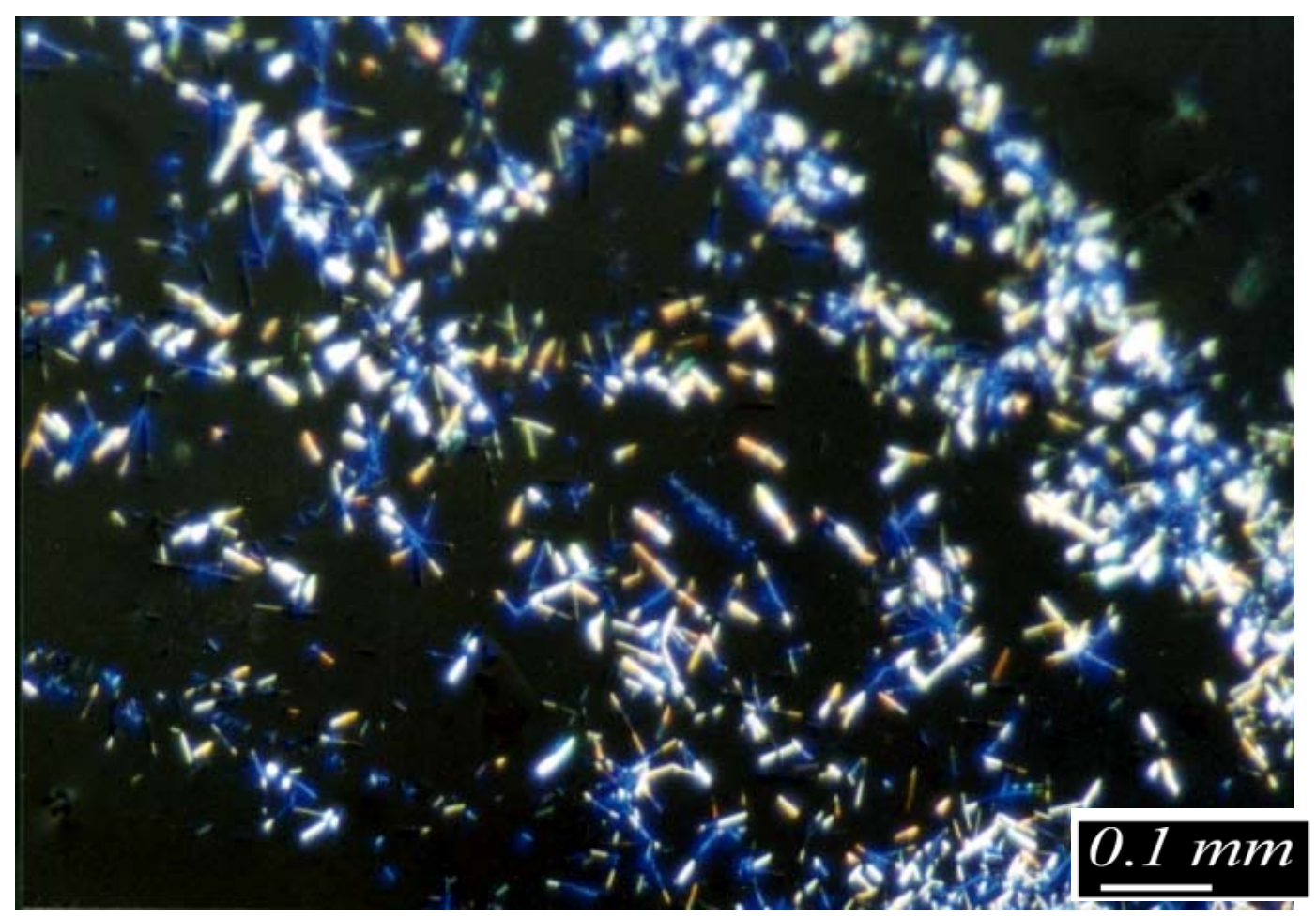

Fig. 1. Optical micrograph of a composite of poly(vinyl alcohol) and $10 \% \mathrm{w} / \mathrm{w}(5 \% \mathrm{v} / \mathrm{v})$ $\mathrm{K}_{2}\left[\mathrm{Pt}(\mathrm{CN})_{4}\right] \mathrm{Br}_{0.3}$; between crossed polarizers

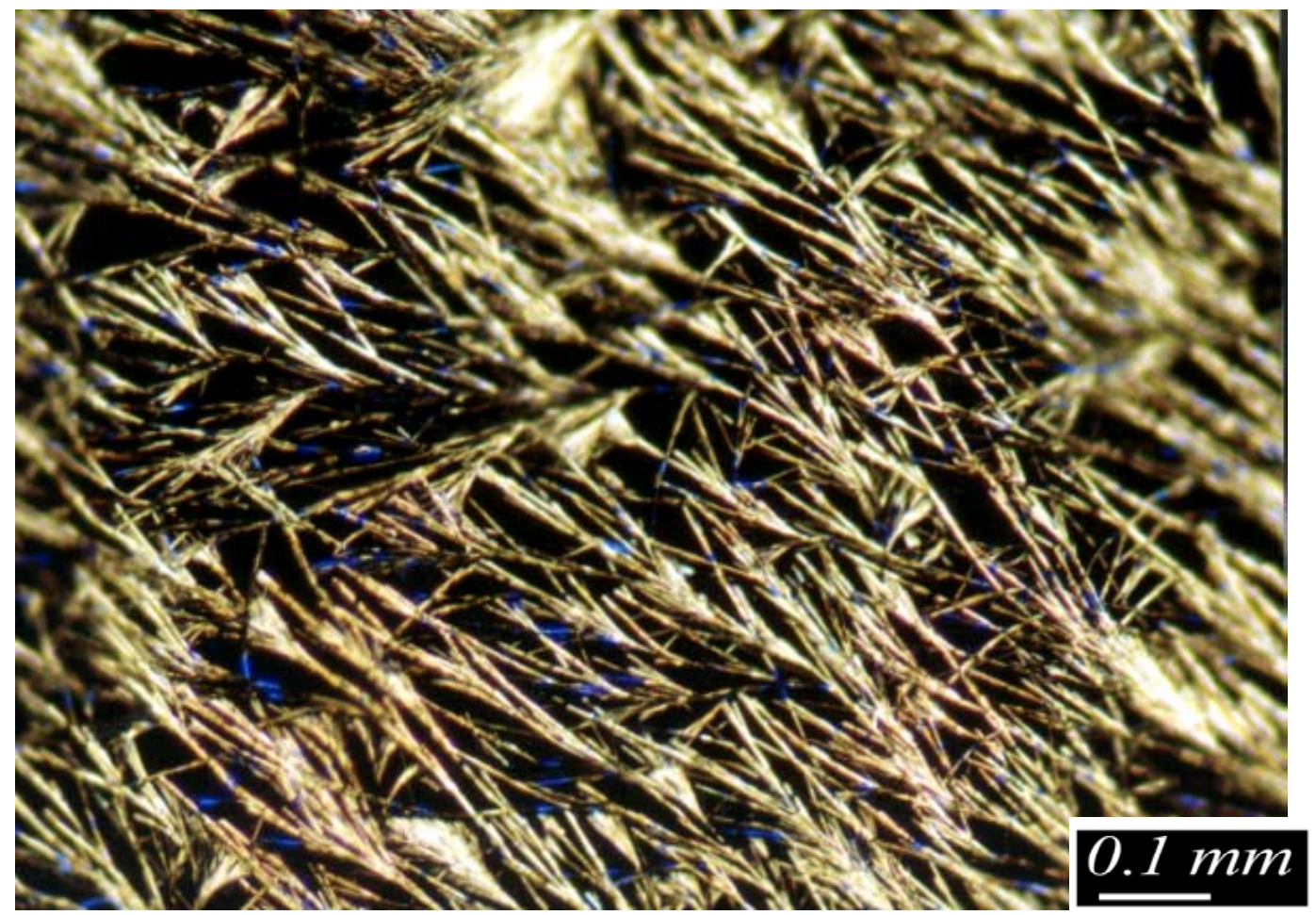

Fig. 2. Optical micrograph of a composite of poly(vinyl alcohol) and $40 \% \mathrm{w} / \mathrm{w}(25 \%$ $\mathrm{v} / \mathrm{v}) \mathrm{K}_{2}\left[\mathrm{Pt}(\mathrm{CN})_{4}\right] \mathrm{Br}_{0.3}$; between crossed polarizers 


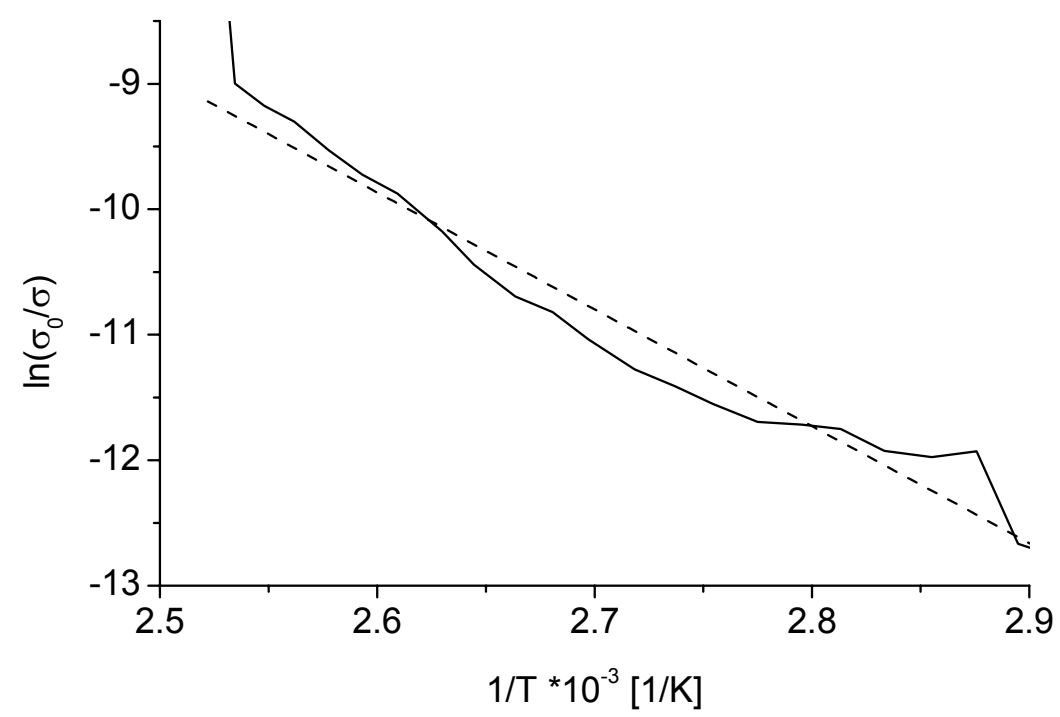

Fig. 3. Temperature $(T)$ dependence of the electrical conductivity $(\sigma)$ of a composite of poly (vinyl alcohol) and $20 \% \mathrm{w} / \mathrm{w}(11 \% \mathrm{v} / \mathrm{v}) \mathrm{K}_{2}\left[\mathrm{Pt}(\mathrm{CN})_{4}\right] \mathrm{Br}_{0.3}$. Also indicated is the linear regression line

The poly(vinyl alcohol) composites with $\mathrm{K}_{2}\left[\mathrm{Pt}(\mathrm{CN})_{4}\right] \mathrm{Br}_{0.3}$ contents up to $17 \% \mathrm{v} / \mathrm{v}$ could be drawn at ca. $70^{\circ} \mathrm{C}$ to draw ratios of $7-8$. At $\mathrm{K}_{2}\left[\mathrm{Pt}(\mathrm{CN})_{4}\right] \mathrm{Br}_{0.3}$ contents of $25 \% \mathrm{v} / \mathrm{v}$ or above, the films were too brittle for drawing. The drawn films exhibited only a moderate optical anisotropy of the dominating absorption band at $350 \mathrm{~nm}$ in UV/vis spectra. In the composites with $17 \% \mathrm{v} / \mathrm{v} \mathrm{K} \mathrm{K}_{2}\left[\mathrm{Pt}(\mathrm{CN})_{4}\right] \mathrm{Br}_{0.3}$, the absorption of light polarized parallel to the drawing axis was only $30 \%$ higher than of light polarized perpendicular to the drawing axis. In the visible wavelength region, no dichroism could be observed. Tetracyanoplatinate complexes frequently show photoluminescence [27-30], and accordingly drawn composites with $17 \%$ v/v $\mathrm{K}_{2}\left[\mathrm{Pt}(\mathrm{CN})_{4}\right] \mathrm{Br}_{0.3}$ were investigated with photospectroscopy. At an excitation at $370 \mathrm{~nm}$, a strong emission arose with a maximum at $435 \mathrm{~nm}$ which corresponds to the emission of the bulk $\mathrm{K}_{2}\left[\mathrm{Pt}(\mathrm{CN})_{4}\right] \mathrm{Br}_{0.3}$. At $435 \mathrm{~nm}$, the intensity emitted with the polarization direction perpendicular to the drawing axis was 3 times above that emitted parallel (Fig. 4), indicating a preferential orientation of the platinum arrays in the orientation direction since emission is more intense for polarization parallel to the tetracyanoplatinate plane [29], i.e. perpendicular to the direction of the platinum array in $\mathrm{K}_{2}\left[\mathrm{Pt}(\mathrm{CN})_{4}\right] \mathrm{Br}_{0.3}$.

\section{Composites with $\left[\mathrm{Pt}\left(\mathrm{NH}_{3}\right)_{4}\right]\left[\mathrm{PtCl}_{4}\right]$ (Magnus' green salt)}

Magnus' green salt was prepared according to the literature using the Magnus' pink salt modification [8]. Magnus' pink salt is a metastable crystal modification of Magnus' green salt with Pt-Pt distances exceeding $5 \AA[8,32]$. The pink salt is soluble in hydrochloric acid from which $\left[\mathrm{Pt}\left(\mathrm{NH}_{3}\right)_{4}\right]\left[\mathrm{PtCl}_{4}\right]$ crystallizes in the green form at room temperature. Upon combination of poly(vinyl alcohol) and $\left[\mathrm{Pt}\left(\mathrm{NH}_{3}\right)_{4}\right]\left[\mathrm{PtCl}_{4}\right]$ solutions followed by solvent evaporation, films of the composite materials were obtained, with thicknesses between 50 and $100 \mu \mathrm{m}$ and Magnus' green salt contents of $5-30 \%$ $\mathrm{w} / \mathrm{w}\left(2.2-15 \% \mathrm{v} / \mathrm{v}\right.$, calculated with densities of $3.1 \mathrm{~g} / \mathrm{cm}^{3}$ for Magnus' green salt [31] and $1.3 \mathrm{~g} / \mathrm{cm}^{3}$ for poly(vinyl alcohol) [24]). In the optical microscope, green needles with typical lengths around $50 \mu \mathrm{m}$ and aspect ratios on the order of 10 were observed in the composites (Fig. 5). 


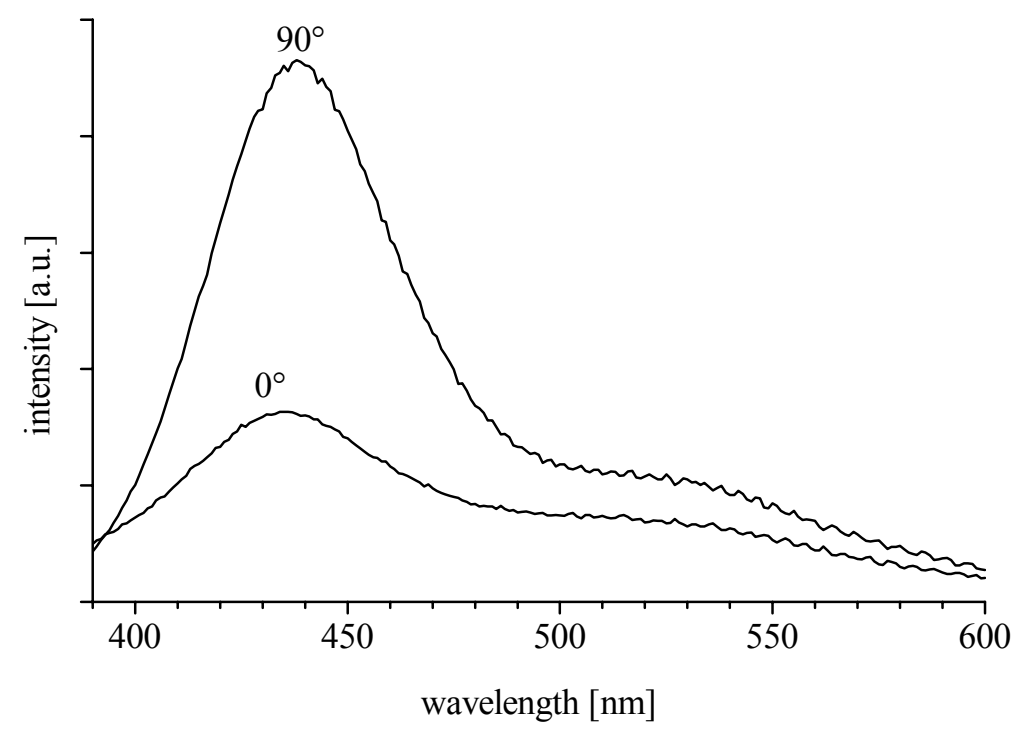

Fig. 4. Polarized emission spectra of a composite of poly(vinyl alcohol) and $30 \% \mathrm{w} / \mathrm{w}$ $(17 \% \mathrm{v} / \mathrm{v}) \mathrm{K}_{2}\left[\mathrm{Pt}(\mathrm{CN})_{4}\right] \mathrm{Br}_{0.3}$, with the emitted component parallel $\left(0^{\circ}\right)$ and perpendicularly $\left(90^{\circ}\right)$ polarized with respect to the drawing axis

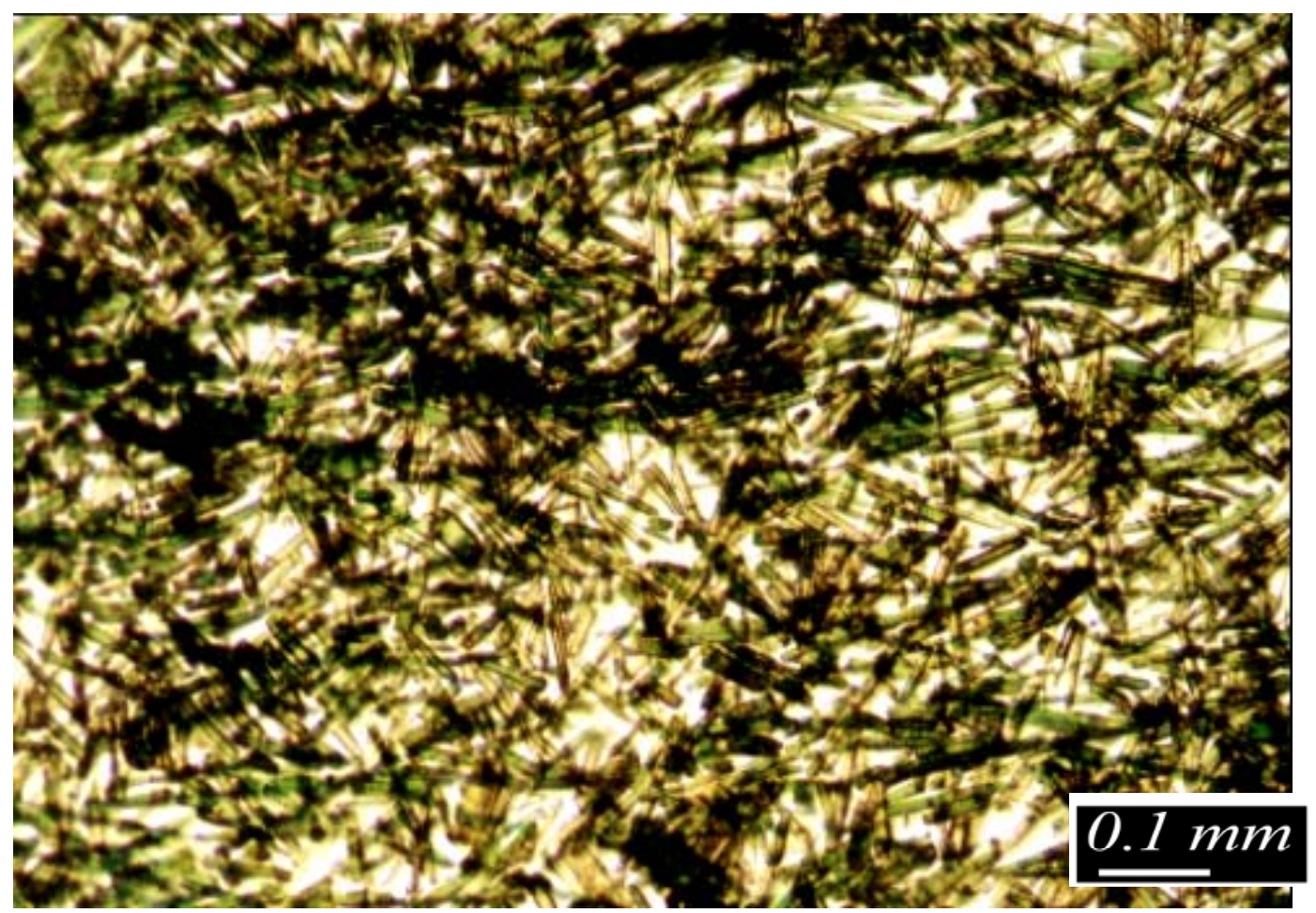

Fig. 5. Optical micrograph of a composite of poly(vinyl alcohol) and $20 \% \mathrm{w} / \mathrm{w}(9.5 \%$ $\mathrm{v} / \mathrm{v})\left[\mathrm{Pt}\left(\mathrm{NH}_{3}\right)_{4}\right]\left[\mathrm{PtCl}_{4}\right]$

The electrical conductivity was measured for samples containing $15 \% \mathrm{w} / \mathrm{w}(6.9 \%$ $\mathrm{v} / \mathrm{v}), 20 \% \mathrm{w} / \mathrm{w}(9.5 \% \mathrm{v} / \mathrm{v})$, and $30 \% \mathrm{w} / \mathrm{w}(15 \% \mathrm{v} / \mathrm{v})\left[\mathrm{Pt}\left(\mathrm{NH}_{3}\right)_{4}\right]\left[\mathrm{PtCl}_{4}\right]$. For the first material $(6.9 \% \mathrm{v} / \mathrm{v})$, the conductivity was below $10^{-7} \mathrm{~S} / \mathrm{cm}$, while the values of the composites with the other two $\left[\mathrm{Pt}\left(\mathrm{NH}_{3}\right)_{4}\right]\left[\mathrm{PtCl}_{4}\right]$ contents were approximately $5 \cdot 10^{-5}$ $\mathrm{S} / \mathrm{cm}$. It appears, therefore, that the percolation threshold was in the region of $8 \% \mathrm{v} / \mathrm{v}$ 
$\left[\mathrm{Pt}\left(\mathrm{NH}_{3}\right)_{4}\right]\left[\mathrm{PtCl}_{4}\right]$, i.e. similar to that found in the composites with $\mathrm{K}_{2}\left[\mathrm{Pt}(\mathrm{CN})_{4}\right] \mathrm{Br}_{0.3}$. The electrical conductivity between $310-380 \mathrm{~K}$ followed the approximate relationship described above for the composites with $\mathrm{K}_{2}\left[\mathrm{Pt}(\mathrm{CN})_{4}\right] \mathrm{Br}_{0.3}$, and an activation energy for the conduction process of $0.5 \mathrm{eV}$ was calculated. Both the bulk conductivity and activation energy were close to the values reported for Magnus' green salt $\left(10^{-2}\right.$ $2 \cdot 10^{-6} \mathrm{~S} / \mathrm{cm}$, depending on the amount of impurities, and $0.2-0.4 \mathrm{eV}$, respectively) [17].

The poly(vinyl alcohol) composites with $5-30 \%$ w/w $(2.2-15 \% \mathrm{v} / \mathrm{v})$ Magnus' green salt could be drawn at $70^{\circ} \mathrm{C}$ to draw ratios of $4-8$. The UV/vis spectra showed strong absorptions in the visible wavelength range due to several $d-d$ transitions in Magnus' green salt [13]. The influence of the absorption on the angle between the polarization plane of the incident light and the drawing axis was moderate, but a difference extended over the entire visible wavelength range (Fig, 6, the polymer matrix did not absorb significantly in the regarded wavelength range). However, this difference was sufficient to cause a dichroism visible by the eye; the samples appeared green for parallel and yellow for perpendicular orientation between the polarization and the drawing direction, which is typical of Magnus' green salt [13].

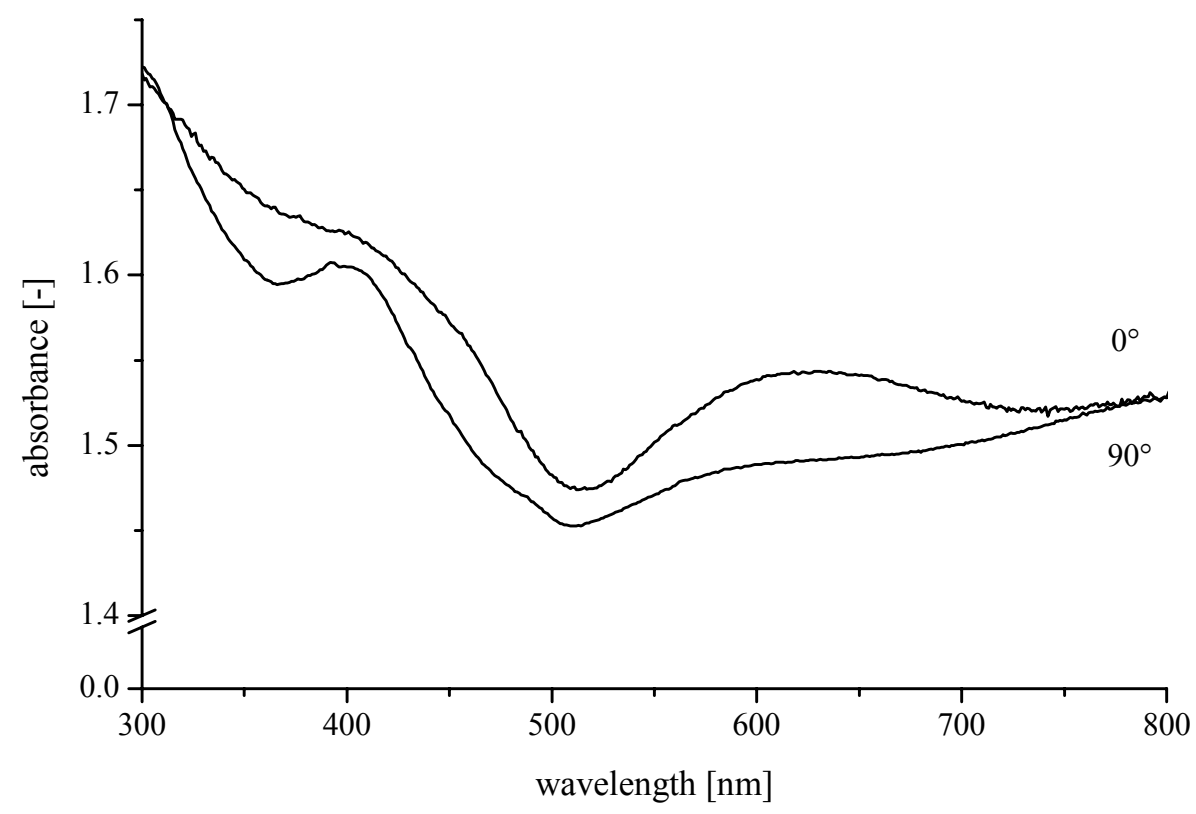

Fig. 6. Polarized UV/vis spectra of a $5 \times$ drawn composite film of poly(vinyl alcohol) and $20 \% \mathrm{w} / \mathrm{w}(9.5 \% \mathrm{v} / \mathrm{v})\left[\mathrm{Pt}\left(\mathrm{NH}_{3}\right)_{4}\right]\left[\mathrm{PtCl}_{4}\right]$, with the polarization direction parallel $\left(0^{\circ}\right)$ and perpendicular $\left(90^{\circ}\right)$ to the drawing axis

\section{Composites with $\left[\mathrm{Pt}\left(\mathrm{NH}_{2} \mathrm{OC}\right)_{4}\right]\left[\mathrm{PtCl}_{4}\right]$}

$\left[\mathrm{Pt}\left(\mathrm{NH}_{2} \mathrm{Oc}\right)_{4}\right]\left[\mathrm{PtCl}_{4}\right](\mathrm{Oc}=$ octyl) was synthesized according to the literature [8] by combination of in situ prepared $\left[\mathrm{Pt}\left(\mathrm{NH}_{2} \mathrm{Oc}\right)_{4}\right] \mathrm{Cl}_{2}$ and $\mathrm{K}_{2}\left[\mathrm{PtCl}_{4}\right]$. The resulting pink $\left[\mathrm{Pt}\left(\mathrm{NH}_{2} \mathrm{Oc}\right)_{4}\right]\left[\mathrm{PtCl}_{4}\right]$ complex is soluble in various organic solvents at $60-80^{\circ} \mathrm{C}$ and forms gels upon cooling to room temperature at concentrations as low as $1 \% \mathrm{w} / \mathrm{w}$ [8]. For preparation of polymer-based composites, chloroform solutions containing poly (methyl methacrylate) and $\left[\mathrm{Pt}\left(\mathrm{NH}_{2} \mathrm{OC}\right)_{4}\right]\left[\mathrm{PtCl}_{4}\right]$ were cooled from $60^{\circ} \mathrm{C}$ to room temperature, whereupon $\left[\mathrm{Pt}\left(\mathrm{NH}_{2} \mathrm{Oc}\right)_{4}\right]\left[\mathrm{PtCl}_{4}\right]$ slowly formed gels. After gelation, the solvent was evaporated resulting in films with $60-100 \mu \mathrm{m}$ thickness and a 
$\left[\mathrm{Pt}\left(\mathrm{NH}_{2} \mathrm{Oc}\right)_{4}\right]\left[\mathrm{PtCl}_{4}\right]$ content of $10-70 \% \mathrm{w} / \mathrm{w}(8-65 \% \mathrm{v} / \mathrm{v}$, calculated with densities of $1.50 \mathrm{~g} / \mathrm{cm}^{3}$ for $\left[\mathrm{Pt}\left(\mathrm{NH}_{2} \mathrm{Oc}\right)_{4}\right]\left[\mathrm{PtCl}_{4}\right]$ as was determined with a helium pycnometer and $1.19 \mathrm{~g} / \mathrm{cm}^{3}$ for poly(methyl methacrylate) (PMMA) [24]). The network formed by $\left[\mathrm{Pt}\left(\mathrm{NH}_{2} \mathrm{Oc}\right)_{4}\right]\left[\mathrm{PtCl}_{4}\right]$ crystallites was readily detected in the final composites (Fig. 7 ).

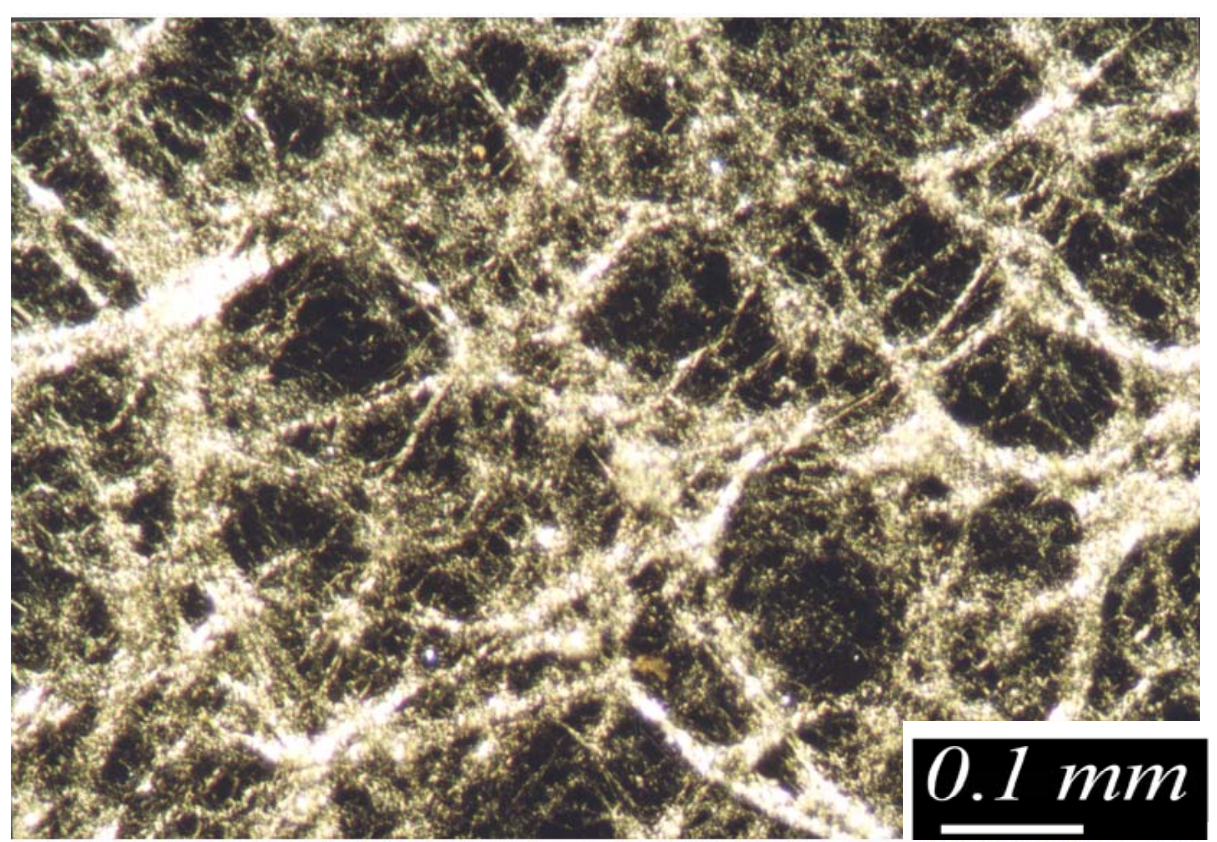

Fig 7. Optical micrograph of a composite of poly (methyl methacrylate) and $40 \% \mathrm{w} / \mathrm{w}$ $(35 \% \mathrm{v} / \mathrm{v})\left[\mathrm{Pt}\left(\mathrm{NH}_{2} \mathrm{Oc}\right)_{4}\right]\left[\mathrm{PtCl}_{4}\right]$ between crossed polarizers

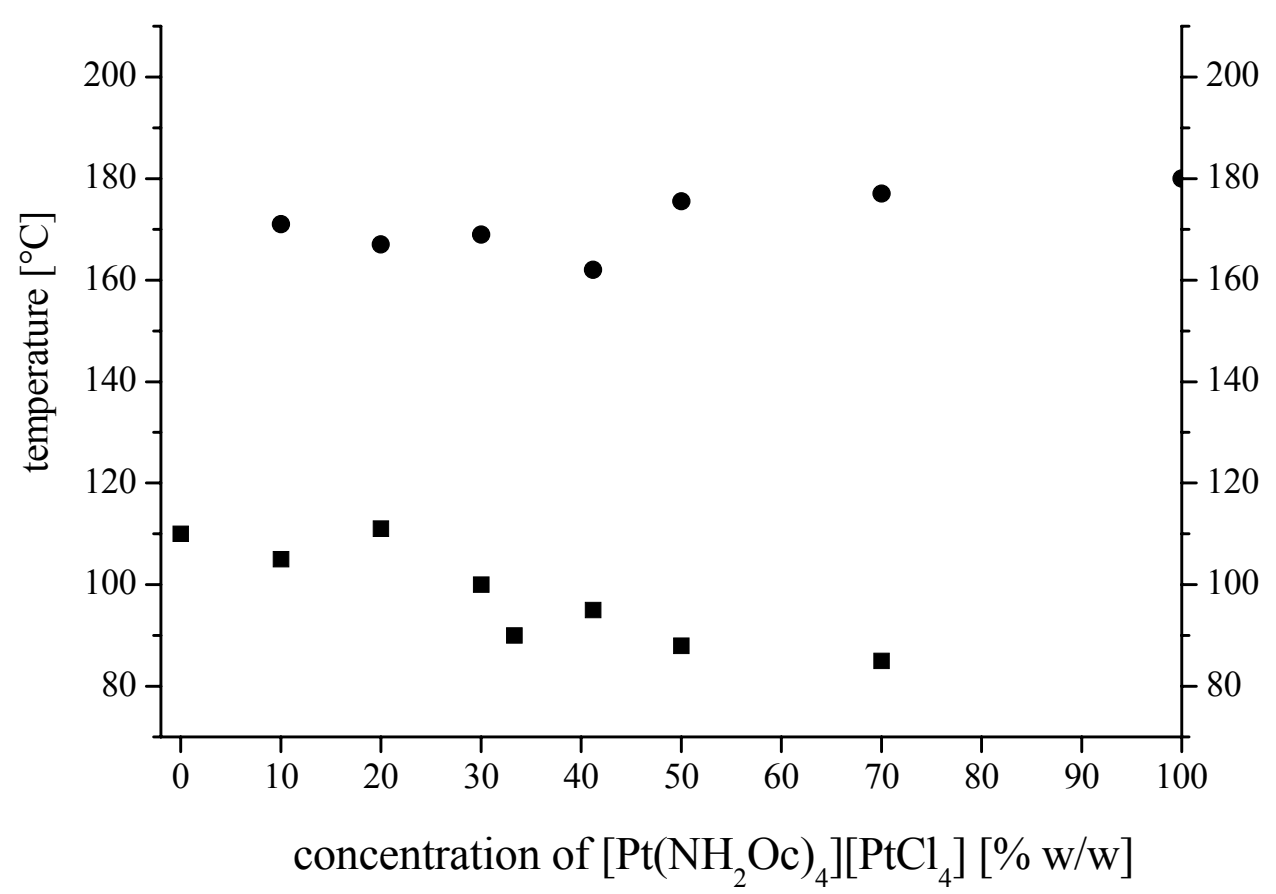

Fig. 8. Glass transition temperatures (squares) of poly(methyl methacrylate) and decomposition temperatures (circles) of $\left[\mathrm{Pt}_{(}\left(\mathrm{NH}_{2} \mathrm{Oc}\right)_{4}\right]\left[\mathrm{PtCl}_{4}\right]$ in composites of these two substances as a function of the concentration of $\left[\mathrm{Pt}\left(\mathrm{NH}_{2} \mathrm{Oc}\right)_{4}\right]\left[\mathrm{PtCl}_{4}\right]$ 
The glass transition temperature $\left(T_{\mathrm{g}}\right)$ was determined for composites and, for comparison, neat PMMA films prepared with the same procedure (concentrations, drying procedure etc.) as the composite films, cf. Fig. 8. Interestingly, the glass transition temperature of poly(methyl methacrylate) (PMMA) decreased gradually from $110^{\circ} \mathrm{C}$ of the neat polymer to $85^{\circ} \mathrm{C}$ for a polymer content of $30 \% \mathrm{w} / \mathrm{w}(35 \% \mathrm{v} / \mathrm{v})$. The systematic dependence of the glass transition temperature of PMMA on the composite composition strongly suggests a certain degree of miscibility of the $\left[\mathrm{Pt}\left(\mathrm{NH}_{2} \mathrm{Oc}\right)_{4}\right]\left[\mathrm{PtCl}_{4}\right]$ and the polymer. The decrease in $T_{\mathrm{g}}$ with decreasing PMMA content arises as a typical feature of miscibility with another macromolecule or supramolecular structure, respectively.

\section{Conclusions}

Composites of polymers and quasi-one-dimensional platinum compounds were obtained by mixing the two components in homogeneous solution followed by solvent evaporation. The composites exhibited typical properties of the inorganic compounds, such as dichroism, photoluminescence, or semiconductivity. In the latter case, the conductivity above the percolation threshold around $8-10 \% \mathrm{v} / \mathrm{v}$ was of the order of the values characteristic of the pure Pt-compounds. The examples presented offer promising perspectives for, e.g., the preparation of highly dichroic or conductive composites using e.g. partially oxidized platinum compounds. Since the quasi-onedimensional platinum compounds are typically stable up to more than $100^{\circ} \mathrm{C}$, this aspect does not limit potential technical applications.

Acknowledgement: We are indebted to Christian Mensing for electrical conductivity measurements.

[1] Carneiro, K.; in "Electronic Properties on Inorganic Quasi-one-dimensional Compounds", Monceau, P., editor; D. Reidel, Dordrecht 1985.

[2] Miller, J. S.; Epstein, A. J.; Prog. Inorg. Chem. 1976, 20, 1.

[3] Kagoshima, S.; Nagasawa, H.; Sambongi, T.; "One-dimensional Conductors"; Springer, Berlin 1988.

[4] Yersin, H.; Gliemann, G.; Ber. Bunsenges. 1975, 79, 1050.

[5] Krogmann, K.; Hausen, H.-D.; Z. Anorg. Allg. Chem. 1968, 358, 67.

[6] Comès, R.; Lambert, M.; Launois, H.; Zeller, H. R.; Phys. Rev. B 1973, 8, 571.

[7] Holzapfel, W.; Yersin, H.; Gliemann, G.; Z. Krist. 1981, 157, 47.

[8] Bremi, J.; Brovelli, D.; Caseri, W.; Hähner, G.; Smith, P.; Tervoort, T.; Chem. Mater. 1999, 11, 977.

[9] Magnus, G.; Pogg. Ann. 1828, 14, 239.

[10] Magnus, G.; Ann. Chim. Phys. Sér. 2 1829, 40, 110.

[11] Knop, W.; Ann. Chem. Pharm. (Liebig's Ann.) 1842, 43, 111.

[12] Yamada, S.; Bull. Chem. Soc. Jpn. 1951, 24, 125.

[13] Rodgers, M. L.; Martin, D. S.; Polyhedron 1987, 6, 225. 
[14] Martin Jr., D. S.; Rush, R. M.; Kroening, R. F.; Fanwick, P. E.; Inorg. Chem. 1973, $12,301$.

[15] Peyrone, M.; Ann. Chem. Pharm. 1844, 51, 1.

[16] Yamada, S. J.; Am. Chem. Soc. 1951, 73, 1579.

[17] Interrante, L. V.; J. Chem. Soc., Chem. Commun. 1972, 302.

[18] Rao, C. N. R.; Bhat, S. N.; Inorg. Nucl. Chem. Lett. 1969, 5, 531.

[19] Mehran, F.; Scott, B. A.; Phys. Rev. Lett. 1973, 31, 99.

[20] Summa, M.; Scott, B. A.; Inorg. Chem. 1980, 19, 1079.

[21] Heffels, W.; Friedrich, J.; Darribère, C.; Teisen, J.; Interewicz, K.; Bastiaansen, C.; Caseri, W.; Smith, P.; Recent Res. Devel., Macromol. Res. 1997, 2, 143.

[22] Van der Pawn, L .J.; Philips Res. Reports 1958, 13, 1.

[23] Abys, J. A.; Enright, N. P.; Gerdes, H. M.; Inorg. Synth. 1979, $19,4$.

[24] Brandrup, J.; Immergut, E. H.; "Polymer Handbook"; John Wiley \& Sons, New York 1989.

[25] Interrante, L. V.; Adv. Chem. Ser. 1976, 150, 1.

[26] Tanaka, M.; Kojima, N.; Ajiro, Y.; Ban, T.; Tsujikawa, I.; Synth. Met. 1987, 19, 967.

[27] Gliemann, G.; Yersin, H.; Struct. Bond. 1985, 62, 87.

[28] Levy, L. A.; J. Chem. Soc. (London) 1912, 101, 1081.

[29] Moreau-Colin, M. L.; Struct. Bond. 1972, 10, 67.

[30] Moncuit, C.; Poulet, H.; J. Phys. Radium 1962, 23, 353.

[31] Atoji, M.; Richardson, J. W.; Rundle, R. E. J.; Am. Chem. Soc. 1957, 79, 3017. 